\title{
Teaterets pedagogiske muligheter - i regi av Bakhtins dialogforståelse
}

\author{
Trond Eriksen
}

Roland Barthes beskriver fortellingen som et uttrykk for selve livet (Barthes, 1977). Gjennom fortellingen søker mennesket å begripe seg selv og det samfunnet de lever i. Teateret er en gammel arena der fortellinger ytres. Her kommer følelser, ønsker, vilje og intensjoner til uttrykk. Med forankring i dialogbegrepet til Bakhtin skal jeg i dette kapittelet prøve å lokalisere et pedagogisk potensial i møtet mellom studenter og et teaterstykke. Ulike stemmer møtes og utfordrer hverandre der det emosjonelle engasjementet står sentralt. Spørsmålet er om det finnes kunnskapsbygging i slike møter.

\section{Teateret - både tekst og opplevelse}

Jeg ønsker å se nærmere på hvordan teater kan brukes i undervisning. Det kan ligge ymse pedagogiske motiver til grunn når teateret gis plass i undervisningen. Disse kan variere fra ønsket om å presentere bestemte teaterstykker som en del av vår felles kulturelle kanon, eller bruke teateret som tekst og inngang til aktuelle faglige tema. Teater og drama brukes også som læringsform ved at elevene selv spiller teater og går inn i stykkets rollefigurer, setter opp egne rollespill eller deltar i interaktive teaterforestillinger der de gjennom innspill og alternative forslag kan styre forestillingens handling og innhold i ulike retninger. Tilskuerstyrte forestillinger finner vi særlig i forumteateret. Her inviteres tilskuerne til 
aktiv deltakelse ved å spille inn egne løsningsforslag slik at handlingen stadig endres. Stykkets tematikk vil ofte speile sosial urett i ulike former, og tanken er at tilskuerne gjennom deltakelse og innflytelse på teaterstykkets gang vil bevisstgjøres eget ansvar og egne muligheter for endring også i den virkelige verden (Boal, 1985; Engelstad, 2004). En litt annen variant av det interaktive teateret finner vi hos skuespiller Torild Jacobsen. I tospann med professor i medisin Anders Bærheim, har hun utviklet en form for intimteater der medisinstudenter settes i utfordrende kommunikasjonssituasjoner. Jacobsen går inn i ulike pasientroller, mens studentene går inn i rollen som lege. Ansikt til ansikt går dialogen ut i vanskelig og ukjent farvann, med medstudenter som tilskuere. Fra sidelinjen kan Bærheim bryte inn i forestillingen/dialogen, enten for å kommentere eller invitere medstudenter til innspill. Disse avbrytelsene skaper brudd i fiksjonen samtidig som de danner materialet for teaterstykkets videre handling. Denne stadige vekslingen mellom den virkelige og fiksjonelle konteksten representerer et brudd med "den fjerde veggen", eller den tenkte veggen som ligger mellom det som utspiller seg på scenen og tilskuerne i salen (Jacobsen \& Baerheim, 2010, s. 9). Jacobsens intimteater er et eksempel på teater i undervisning. Overordnet kan vi si at bruken av teater i undervisningen må ha en tydelig hensikt og en pedagogisk intensjon, svarende til undervisningens hva og hvordan. I dette ligger involvering av tilskuerne, det være seg direkte og styrende som i Boals forumteater eller som refleksjoner i etterkant. Det å bruke teater i undervisningen begrunnes ofte med teaterets mulighet til å dramatisere menneskets tilstander og skjebner slik at tilskuerne selv får muligheten til å skape mening gjennom opplevelse. Med andre ord inviterer teateret til utforskning og evaluering av våre verdier, det være seg sosialt, politisk, moralsk og etisk (Pammenter, 2013, s. 84). Teater og drama åpner altså opp for mange pedagogiske settinger og muligheter. I denne omgang vil jeg rette blikket mot teateret som alternativ tekst inn i faglig tematikk. Tanken er at det ligger pedagogiske muligheter i samspillet mellom student og teaterstykke. I det følgende skal jeg forsøke å lokalisere hvor dette mulighetsrommet ligger, og hva som inngår i det. Vi kan innledningsvis trekke frem opplevelsen, handlingen og det emosjonelle engasjementet som to sentrale, og også sammenfallende, trekk ved det å se et teaterstykke. Det å oppleve noe, og det å la seg engasjere emosjonelt, er teaterets formål og tilskuernes ønske. Derfor kan det være formålstjenlig å rette blikket mot nettopp opplevelsen og det emosjonelle engasjementet i søken etter teaterets pedagogiske potensial. Her må det presiseres at en teateropplevelse 
er både umiddelbar og distansert. Det umiddelbare er opplevelsen tilskueren har her og nå, idet stykket fremføres. Denne opplevelsen bærer tilskueren med seg etter at forestillingen er over, og kan være en kilde for refleksjon i ettertid. Opplevelsen, og det som skapte opplevelsen, perspektiveres, vurderes og endres gjennom det distanserte og tilbakeskuende blikket. Dette kan høres banalt ut, men i pedagogisk sammenheng viser dette til et viktig skille. Både det umiddelbare og distanserte i teateropplevelsen åpner opp for ulike pedagogiske mulighetsrom: Det kan ligge læring i øyeblikkets opplevelse, i det pågående møtet mellom tilskuerens forståelseshorisont og teaterstykkets fortelling, og det kan ligge læring i det å se sin egen opplevelse med et distansert, reflekterende og retrospektivt blikk. Det distanserte blikket kan gjøres individuelt eller sammen med andre studenter i en planlagt didaktisk kontekst. Felles for både den umiddelbare opplevelsen, og det distanserte blikket, er at studentenes faglige begrepsarsenal har betydning. Fokus rettes altså mot opplevelsen her og nå. Dette valget fordrer en liten begrepsmessig presisering: Når studentene ser teaterstykket, defineres de som tilskuere. Idet teaterstykket avsluttes og skuespilleren applauderes av scenen, defineres de som studenter. Dette for å markere et skille mellom to ulike posisjoner, svarende til det umiddelbare og det distanserte. Artikkelens empiriske grunnlag er hentet fra et møte mellom masterstudenter i helsefag ved Universitetet i Tromsø og teaterstykket Langligger (Teater Fusentast, Trondheim 2017) av Coby Omvlee. Til dette har jeg laget et lite, metodisk opplegg for å lokalisere og begrepsfeste studentenes umiddelbare teateropplevelse. Men før vi kommer nærmere inn på den metodiske gjennomføringen samt presentasjon og drøfting av empiri, er det på sin plass å si noe om studentene, teaterstykket og emnet teaterstykket er koblet til, samt det teoretiske grunnlaget som drøftingen er forankret i.

\section{Studenten og teaterstykket}

I studieporteføljen til masterutdanningen i helsefag og sykepleie ved UiT Norges arktiske universitet finnes emnet Utviklingstrekk $i$ helsepolitikk og helsetjenesten, som «retter fokus mot dagens helsepolitikk og hvilken betydning denne får for utøvelse og organisering av helsefaglige profesjoners arbeid, for brukernes rettigheter og plikter, for fordeling og tilgjengelighet av helsetjenester i befolkningen». I forlengelsen av dette er det definert læringsutbyttebeskrivelser der studentene skal kunne «beskrive og kritisk diskutere 
sammenhenger mellom helsepolitikk, helsefaglig profesjonsutøvelse og brukernes posisjon», «selvstendig fortsette egen kompetanseutvikling om tema» og «anvende ferdigheter som er tilegnet i emnet i diskusjoner med kollegaer, ledere og allmenheten om konsekvenser av helsepolitikken» (UiT, 2017). Studentene ved dette masterprogrammet har bakgrunn fra ulike profesjoner, noe som betyr at gruppen har tverrfaglig representasjon. Studentene har også i ulik grad praksiserfaring innenfor sin profesjon. I forbindelse med gjennomføringen av emnet våren 2017 åpnet det seg en mulighet til å bruke teaterstykket Langligger i undervisningen. Langligger er et dokumentarisk teaterstykke basert på Omvlee sine egne erfaringer som lengeliggende pasient etter en bilulykke. Konsekvensen var en alvorlig skade i tynntarmen. Etter ambulansetransport, stabilisering og de første medisinske vurderingene fikk hun beskjed om at skaden skulle la seg relativt greit behandle, og at hun straks ville være ute av sykehuset igjen. Hun ble liggende i ett år på sykehus og ulike rehabiliteringsinstitusjoner, og hvor hun i denne perioden gjennomgikk flere operasjoner samt opplevde kritiske og livstruende faser i sitt pasientløp. Møtet med helsevesenet ble for Omvlee både en tankevekkende og ambivalent affære. Som hun selv uttrykker det i stykkets åpning: «Av det samme helsevesenet ble jeg først reddet, så nesten tatt av dage, reddet på nytt, så nesten tatt av dage en gang til før jeg ble endelig reddet» (Omvlee, 2017). Omvlee har altså gjort seg noen erfaringer i møtet med helsevesenet, erfaringer på godt og vondt, og med et påfølgende sterkt personlig engasjement rundt temaer som helsevesenets organisering, struktur, finansieringsmodeller og ikke minst pasientsikkerhet. Dette er tanker og erfaringer hun ønsker å dele med andre, hun ønsker respons, hun ønsker engasjement, og hun ønsker endring. Samtidig ser vi at teaterstykkets innhold helt klart korresponderer med emnets innhold og læringsutbytter. Dermed kan Langligger fungere som en alternativ vei inn i emnets tematikk, med de mulighetene dette gir. Omvlee har altså en historie å fortelle, en historie ladet med intensjoner, og historien fortelles i form av et teaterstykke. Teateret vil særlig i form, men også i innhold, representere noe annet enn det studentene vanligvis møter innenfor universitetets helsefaglige undervisningstradisjoner. Først og fremst vil et teater appellere til emosjonell deltakelse og innlevelse. Det ligger i teaterets natur at en forestilling skal være noe mer enn en objektiv og nøytral gjengivelse av et saksforhold eller tema. Følelser skal vekkes. Et teater er heller ikke en pålitelig og vitenskapelig kilde i akademisk forstand, og innholdet som ytres, er heller ikke forskningsbasert. Men et teater kan tilby nye og 
uventede veier inn i ulike saksforhold, og slik engasjere et bredere spekter av studentenes vurderings- og refleksjonspotensial. Som fortelling kan teateret vitalisere undervisningen og åpne opp for større perspektivmobilitet. Teater er fortelling, og fortellingen har alltid stått sentralt i menneskets forsøk på både forstå og organisere den verden de lever i. Dermed er det på sin plass å si noen ord som knytter fortellingen til kunnskapsbygging.

\section{Fortellingen - både historie og diskurs}

På tvers av ulike kulturer og tidsepoker ser vi fortellingen som en grunnleggende menneskelig uttrykksform. Vi finner den igjen i alle livets små og store hendelser. Barnet som beskriver skoledagen sin i form av fortelling, kolleger som forteller hverandre hvordan påskeferien har vært, hvordan våre tidligere livserfaringer forstås og formidles som fortelling. Det kan også tenkes at vi forstår oss selv som de fortellingene vi skaper om oss selv i våre møter med andre. Våre tanker har fortellingens mønster, og vi søker forståelse, sammenheng og kunnskap om felles historie, kultur og samfunnsstruktur innenfor fortellingens rammer (Lothe, 1994). Fortellingen kan ta mange former, som samtaler rundt et leirbål, eventyr, dans, sang, teater, film, maleri, romaner, brettspill og dataspill. Vi finner fortellingen i huleboernes malerier, i historieskrivernes nedtegnelser, i journalistens vinkling og i politikerens retorikk. Ja, i politiets logger, i helsevesenets journaler, i militærets rapporter og i faglige diskurser kan vi finne spor av fortellingens struktur: Hendelser markerer overganger, og dette settes inn i en språklig utforming med ord, uttrykk og teknikker som skaper opplevelsen av noe som fortelles. Den amerikanske retorikkprofessoren Seymour Chatman beskriver en modell der fortellingens struktur består av elementene historie og diskurs. Historie betegner fortellingens $h v a$, altså handlingen i fortellingen. Historiens diskurs betegner fortellingens hvordan, altså måten det fortelles på (Chatman, 1978). Slik kan vi se at historien om den fiktive Jean Valjean (Les Misérables, 1862) fortelles som roman, teater, film og musikal. Fortellingens hva og hvordan er uløselig knyttet til hverandre. Det som fortelles, eller fortellingens historie, vil preges av hvordan den fortelles, og hvordan den fortelles, vil preges av hva som fortelles. Dette betyr at opplevelsen for den som blir fortalt noe, påvirkes av både hva som fortelles, og hvordan det fortelles. Samtidig må den som blir fortalt noe, bruke sin egen referanseramme for å forstå de fortalte 
begivenhetene, noe som åpner for at fortellingen kan «være et potensial for ny innsikt og forståelse for oss som tolker, enten vi er tilskuere, betraktere, tilhørere eller lesere, ved at referanserammen vår kan bli utfordret» (Braaten, Kulset \& Solum, 2000, s. 12). Dette er en forståelse av fortellingens potensial som ytterligere kommer til uttrykk i filosof og filmteoretiker Murray Smith sin filmteoretiske forståelse. Her viser han hvordan fiksjonelle tekster ber oss revidere de antakelsene og verdiene vi som tilskuere bringer med oss i møtet med det som fortelles. Den fiksjonelle verden kan på sin side foreslå alternative fysiske lover, historier, moralske koder og sosiale ritualer. Han viser også til filosofen Paul Ricoeur, som beskriver hvordan fiksjonelle tekster setter til side vår oppmerksomhet om det virkelige, og hvor vi kan prøve ut nye ideer, nye verdier, nye måter å være til stede i verden på. Et slikt forhold forutsetter at vi tar med oss vår erfaring fra den virkelige verden inn i teksten, eller fortellingen, og at denne igjen kan endre hvordan vi forstår og erfarer verden (Smith, 1995). Ulike fortellinger kan med andre ord bidra med et alternativ, også til tradisjonelle undervisningsmetoder i høyere utdanning. I Langligger møter studentene historien om en lengeliggende pasient, og den fortelles som teater. Det er virkelige hendelser som fortelles, men fortellingens hvordan skjer gjennom bruken av teaterestetiske virkemidler. Dette har betydning for tilskuerens opplevelse. Møtet mellom studentene og Langligger er relasjonelt og et kommunikativt forhold. Et forsøk på å lokalisere de pedagogiske mulighetene må også her forankres i et teoretisk grunnlag. Et teoretisk valg, grunnet i teoretisk refleksjon, leder alltid oppmerksomheten bort fra noe og til noe annet. I dette tilfellet ledes oppmerksomheten primært mot Mikhail Bakhtin og hans perspektiv på dialogen.

\section{Dialogens eksistensielle karakter}

I søken etter teaterets pedagogiske muligheter legges den teoretiske forankringen primært til den russiske språk- og kulturfilosofen Mikhail Bakhtin. Bakhtin beskriver dialogen som grunnlaget for all mellommenneskelig forstålse. Denne dialogiske livsanskuelsen ble særlig utviklet i Bakhtins møte med persongalleriet i Dostojevskijs forfatterskap. Her møter vi ulike karakterer som bærer sine egne stemmer som en «mengde likeverdige bevisstheter med sine respektive verdener» (Bakhtin, 2003, s. 136). Romanens persongalleri utgjør en polyfon, eller flerstemmig, verden av unike stemmer der 
hver enkel karakter hevder sin egen bevisste identitet gjennom dialogiske møter. Dette illustreres særlig godt av karakteren Raskolnikov i Forbrytelse og straff (Dostojevskij, 2001). Etter å ha drept pantelåneren Aljona følger vi Raskolnikovs indre kamp om motiv, begrunnelse, rettferdiggjøring, skyld og straff. Raskolnikovs dialogiske relasjoner, og indre dialog med seg selv, viser en mann som må ta stilling til avgjørende problem i eget liv, eller «de øyeblikk hvor jeget ikke lenger er identisk med seg selv, men befinner seg på grensen til en ny forståelse av seg selv og verden» (Børtnes, 2001, s. 101). Raskolnikovs kvaler, hans runddans med egen samvittighet, dialogene med andre karakterer, de ulike stemmene som gir gjenklang i hans egen indre dialog, viser en selvbevissthet som presses til det ytterste. Raskolnikov er ikke lenger et objekt i Dostojevskijs diskurs, men et subjekt «i sin egen umiddelbare, meningsskapende diskurs» (Bakhtin, 2003, s. 136). Det er denne selvbevisstheten vi som lesere inviteres til å gå i dialog med. Poenget er at den selvbevisste Raskolnikov skapes gjennom dialogiske relasjoner. Uten dialog, ingen Raskolnikov. Dette peker mot menneskets eksistens som grunnleggende dialogisk, i poetiske vendinger uttrykt som dette:

To be means to be for the other, and through him, for oneself. Man has no internal sovereign territory; he is all and always on the boundary; looking within himself, he looks in the eyes of the other or through the eyes of the other ... I cannot do without the other; I cannot become myself without the other; I must find myself in the other, finding the other in me. (Bakhtin, sitert i Wertsch, 1998. s. 116).

Bakhtin beskriver betydningen av den andre med styrke og patos. Uten den andre kan vi ikke se oss selv, ha bevissthet om oss selv, være oss selv. Her klargjøres den andre som grunnlaget for vår eksistens, og dialogen som den primære strukturen i den enkeltes eksistens, «representing a constant exchange between what is already and what is not yet» (Clark \& Holquist, 1984, s. 65). Våre dialogiske møter med hverandre er altså eksistens og endring, noe som er, og noe som kommer til å bli. Dialogiske møter bærer med seg løftet om noe nytt, noe annerledes, ja et opphør av «å være identisk med meg selv og bli en annen for den andre» (Børtnes, 2001, s. 103). Umiddelbart framstår kanskje ideen om «den andre» som noe mystisk. I realiteten kan «den andre» være alt fra naboen vi slår av en prat med, til aviser, vitenskapelige artikler, 
romaner, dikt, plenumsdiskusjoner, fiksjonsfilm etc. Med andre ord alt og alle som uttrykker seg muntlig eller skriftlig (Bakhtin 2005, 1994, 1986, 1981). Men det viktigste her er at alt som ytres, bærer med seg mening, og at denne rettes mot en framtidig respons. Vi sier at ytringen har en adressat, og at både mening og forståelse etableres i møtet mellom det som ytres, og adressatens respons på dette. I dagliglivets små og store samtaler kjennes dette igjen ved at ord og setninger vandrer mellom samtalepartnerne. Vi ser det i overgangen mellom ytringene der den som lytter, selv blir taler ved å respondere på det som er sagt. Dette betyr naturlig nok at alle ytringer er iboende assosiert med minst to stemmer (Wertsch, 1991). Som nevnt kan «den andre», eller vår samtalepartner, ta mange former. I dette tilfellet er det snakk om teater, som i likhet med alle andre verk er innstilt på den andre, eller tilskuerens aktivt svarende forståelse. Denne kan ha som hensikt å «oppdra lesarane, gje dei overtydning, framkalle kritisk respons, eller øve innverknad på elevar og andre som skal føre verket videre. (...) På samme måten som replikken i ein dialog, er det knytt saman med andre verk eller ytringar, både med dei verket svarer til og med dei som svarer på verket» (Bakhtin, 2005, s. 18). Oppsummert kan det hevdes at Bakhtins eksistensielle dialogforståelse tilbyr et godt fotfeste for pedagogisk arbeid. Læringsprosesser er jo noe som ligger i grenseland mellom det som er, og det som kommer til å bli, det stedet der ny mening og forståelse oppstår, der kunnskap etableres og deles, der ny erkjennelse av seg selv og verden skapes. Neste skritt blir å se nærmere på teater gjennom Bakhtins perspektiv.

\section{Teateret som tekst}

Bakhtin beskriver teksten som den umiddelbare virkeligheten der både tankens og opplevelsens virkelighet har sitt utspring. Dette betyr at alle møter mellom mennesker, mellom ulike erfaringer og opplevelser, mellom ulike perspektiver og livsanskuelser er tekst. Disse tekstene kan ta alle mulige former der ytringer er mulig, det være seg prat ansikt til ansikt, litterære verk, film, teater, musikk, bilder, skulpturer, dans og sang. Bakhtin oppfordrer altså til en dyp, rik og raffinert forståelse av tekstbegrepet der vi er i dialog med tekster og gjennom tekster. I dette ligger at tekster er en subjektiv refleksjon av en objektiv verden, og at teksten uttrykker en bevissthet, altså noe som reflekterer (Bakhtin, 1986). Omvlee sitt teaterstykke er hennes subjektive 
refleksjon av sykehusoppholdet. Hun har et ønske om å la sin stemme bli hørt. Hun er en stemme i henvendelse. Måten hun gjør dette på, er gjennom teateret. Teateret er altså det medierende redskapet. Samtidig vet vi at teateret har sitt eget språk, sin egen måte å kommunisere på. Det gjøres noen bevisste teaterestetiske valg som leder tilskuernes blikk, styrer vår opplevelse og inviterer enten til emosjonelt engasjement eller en distansert og kritisk observasjon som i Bertolt Brecht sine stykker. Til dette brukes scenografiske elementer som dekorasjon, sceneelementer, kostymer, belysning og musikk, eller kun en naken scene for å skape et visuelt uttrykk som underbygger og forsterker både handling og ytringer (Gatland, 1998; Dalgard, 1974). Videre gjøres det valg i regi som skaper sammenheng, rytme og rekkefølge, viktige valg som løfter fram ulike tema, forsterker og fokuserer, som leder vår oppmerksomhet. Det er altså en rekke strategiske og kunstneriske valg som i sum utgjør den teksten som Langligger er. I tillegg er det flere stemmer som kommer til uttrykk i stykket: Omvlee spiller seg selv som pasient. Men hun går også ut av rollen, stiller seg på siden, kommenterer og stiller spørsmål rundt sin egen situasjon som pasient og helsevesenets organisering. Hennes pårørende er også tilstedeværende gjennom verbale henvisninger og bilder av brev, tegninger og gaver. Det gjøres også bruk av videosnutter der helsepersonell, helsepolitikere og helsebyråkrater intervjues om de temaene som stykket løfter fram. Langligger er altså en multimodal og flerstemmig tekst, kunstnerisk utformet og formidlet gjennom teaterestetiske virkemidler, og i det multimodale ligger også et element av brudd med «den fjerde veggen». Som tilskuere inviteres vi til å gå i dialog med Langligger, komme de ulike stemmene i møte og gjøre dem til våre egne.

\section{Teateropplevelsen: en dialogisk relasjon}

Som vi har sett, vil enhver ytring rette seg mot en forventet respons. Dette teoretiske perspektivet kan oversettes til et konkret eksempel fra Langligger. I en scene møter vi Omvlee der hun foreller om en bestemt kritisk og livstruende periode. Hun er overført fra sengepost på sykehus til et rehabiliteringssenter. Her ernæres hun oralt, selv om hun på sykehuset hadde behov for intravenøs ernæring. Hver dag går det mer væske ut av kroppen enn inn. Resultatet var at hun ble gradvis svakere, og med en potensiell dødelig forstyrrelse i elektrolyttbalansen. Denne opplevelsen fortelles på følgende måte: 
Rollefiguren Omvlee, kledt i pasientskjorte, står midt på en mørklagt scene. En enkel lyskaster fokuserer Omvlee. I bakgrunnen spilles svak, monoton og illevarslende musikk. Omvlee har et alvorlig og tankefullt blikk mot publikum. Så sier hun: "Jeg er dehydrert, underernært og svekket, spiller ingen rolle om jeg lever videre eller ikke». Så lyses scenen opp. Musikken endrer karakter til litt lystigere og mer melodiøs. Omvlee beveger seg over scenen og setter seg i en sykehusseng, omkranset av ulike medisinske apparater. Så henvender hun seg spørrende og mer direkte til publikum:

Hvordan torde rehabiliteringssenteret å ta meg inn når de visste jeg ikke kunne få ernæring intravenøst? Og på sykehuset visste de at jeg ikke kunne klare meg uten slangen. Kommuniserer de ikke med hverandre?

Omvlee er her i direkte henvendelse, en henvendelse som framprovoserer svar, som foregriper og strukturerer seg selv i svarets retning. Ordene som sies, er bestemt av det som ennå ikke er sagt, de er forutsatt av et framtidig svarende ord, altså tilskuernes respons. Nå kan dette framstå som en formulering av banaliteter. Når noe sies, så forventes det respons. Men det sentrale momentet som Bakhtin her løfter fram, er hvordan tilskuernes forståelse aktiveres slik at ordene tas inn i et allerede eksisterende begrepsarsenal, et arsenal fylt med «specific objects and emotional expressions, and indissolubly merged with the response, with a motivated agreement or disagreement» (Bakhtin, 1994, s. 76). Når Omvlee spør hvordan rehabiliteringssenteret torde ta henne inn tross manglende mulighet til livsnødvendig behandling, ja, så søker hun å skape sitt eget uttrykk på fremmed territorium, opp mot tilskuernes egen horisont. Det er her den dialogiske relasjonen lever og utvikles. Som tilskuer til Langligger bærer den enkelte student med seg holdninger og verdier, egne erfaringer og ikke minst forskningsbasert kunnskap tilegnet gjennom studietiden. Omvlee sine ytringer er et forsøk på å få lest sine egne ord, sitt eget konseptuelle system, innenfor tilskuernes konseptuelle system, slik at «the speaker breaks through the alien conceptual horizon of the listener, constructs his own utterance on alien territory, against his, the listener's apperceptive background (Bakhtin, 1994, s. 77). Når Omvlee spør om sykehus og rehabiliteringssenter ikke kommuniserer med hverandre, så er dette et spørsmål ladet med frustrasjon, tristhet og håp om endring. Tilskuerne på sin side møter Omvlee sin emosjonelt ladede ytring med et 
allerede etablert begrepsapparat der stemmer fra faglitteratur og forelesere er aktivt til stede. I så måte kan vi forvente at tilskuerne, med sin kunnskap om helsepolitikk og helsevesenets organisering, ser betydningen av god og presis kommunikasjonsflyt i helsevesenet. Men Omvlee inviterer til ny forståelse, nye sammenhenger, nye ekspressive betoninger. Eksisterende forståelse befolkes med nye stemmer, det skapes harmoni eller motstand, holdninger og kunnskap utfordres. Men dette skjer ikke betingelsesløst. Stemmene blandes, og mening oppstår i prosesser der vi tar ansvar og krever forfatterskap for de stemmene som selektivt gjøres til våre egne. De ordene Omvlee bruker, er ikke leksikalske rapporteringer, men ord mettet med betydning, ord i kontekst og ord som formidler intensjoner. Dette er ord som tilskuerne må gjøre til sin egne. Slik kan tilskuernes forståelse av begrepet kommunikasjon i helsevesenet utfordres, fylles med ny mening (Bakhtin, 1994). Dette er både kunnskapsbygging og kunnskapsdeling. «Det er når ulike stemmer deltar i dialogen og interagerer i den forstand at dei byggjer på kvarandre og/ eller strir mot kvarandre, at det skjer noko meir enn reproduksjon (Dysthe, 1999, s. 111). Den norske psykolingvisten Ragnar Rommetveit er inne på det samme i sitt intersubjektive perspektiv på læring. Her beskrives adressaten som medforfatter av meningsinnholdet i det som ytres, og ikke den skapningen som det kommuniseres til (Rommetveit, 1999). Ofte kan det forholde seg slik at adressaten mestrer meningsinnholdet i ordene bedre, enn de som ytrer ordene. Slik kan kommunikasjon i helsevesenet knyttes opp mot rutiner, samhandling og kommunikasjonsplattformer, mens Omvlee sitt spørsmål vektlegger konsekvenser og menneskelige enkeltskjebner i et stort system. Samtidig åpner Omvlee sitt spørsmål opp for flere innfallsvinkler og perspektiver i og med at tilskuerne er medforfattere. Ordene kan ikke konverteres fra «manifest språkleg uttrykk til latent meiningsinhald, men heller å tolka som ein sosial protese og eit slags forhandlingsmiddel. Og andre menneske - helst slike som tenkjer litt annleis enn oss - er våre beste hjelparar til å forhandle oss fram til ny forståing» (Rommetveit, 1996, s. 96). Det primære hos både Bakhtin og Rommetveit er at mening og forståelse ikke kan overføres fra person til person, eller fra tekst til person. Mening og forståelse oppstår i dialogen, i samspillet mellom dem som deltar, og der mottakeren er «medprodusent i språkleg formidla meining» (Dysthe, 1996, s. 108). Vi skal nå se på noen eksempler på dette dialogiske samspillet, fra den umiddelbare teateropplevelsen til den mer distanserte refleksjonen om teateropplevelsen og dens innhold. 


\section{Det praktiske opplegget for gjennomføring}

Forestillingen spilles i et av universitetets auditorier. De fysiske omgivelsene er først og fremst innrettet mot tradisjonell undervisning, men auditoriets utforming egner seg også til teaterforestilling. Følgende opplegg er fundert for å lokalisere studentenes egne beskrivelser av den umiddelbare teateropplevelsen:

1. Studentene informeres om opplegget, og det gis kort instruksjon om hva de skal gjøre i det øyeblikket forestillingen er over.

2. Teaterstykket spilles, og studentene er tilskuere til dette.

3. Straks etter forestillingen presenteres følgende tre spørsmål:

a. Hva handler teaterstykket om?

b. Hva opplevde du som det viktigste i stykket?

c. Hvorfor var dette det viktigste?

Spørsmålene vises på storskjerm. Disse besvares individuelt og skriftlig, og det er ingen form for dialog mellom studentene mens spørsmålene besvares. Det settes av cirka 10 minutter til de skriftlige responsene.

4. De skriftlige responsene samles inn.

Overgangen fra det umiddelbare til det distanserte begynner i det øyeblikket studentene starter å verbalisere sin egen opplevelse skriftlig. Den første skriftlige verbaliseringen knyttes tett opp mot opplevelsen, slik at responsene er sterkt preget av et emosjonelt engasjement som fortsatt er sterkt mobilisert og tilstedeværende hos den enkelte. Her ligger også muligheten for studentene å feste i ord de vurderingene som skaper øyeblikkets opplevelse. Idet pennen senkes mot arket, og egne tanker, følelser, vurderinger og refleksjoner formes til skrevne ord, involveres bevisstheten om egen deltakelse og et selv som har respondert på teaterstykkets handling og ytringer. Studenten identifiserer altså både seg selv som deltaker i sin egen teateropplevelse, og de faktiske handlingene og ytringene som ligger til grunn for opplevelsen. Samtidig endrer omgivelsene seg. Lyset slås på, auditoriet vekkes til live og reetableres som lokalitet for undervisning. Forestillingens ulike rekvisitter endrer karakter fra situasjonsdefinerende redskaper til anonyme gjenstander. 
Borte er dramaturgien med lyd- og lyseffekter, og stemmene til Omvlee og de andre har stilnet. De har sagt sitt, orientert mot et forventet svar, en forventet respons, og nå svarer studentene (Bakhtin, 1986). Selv om studentenes svar er umiddelbare og gitt når det emosjonelle engasjementet er aktivt, så er det tydelig at svarene er forankret i et konseptuelt system der de faglige stemmene gjør seg sterkt gjeldende (Bakhtin, 1994). Dette kan illustreres med noen eksempler på studentenes umiddelbare responser på de tre spørsmålene.

\section{Hva handler teaterstykket om?}

På spørsmålet om hva teaterstykket handler om, så ser vi hvordan forholdet mellom pasient, system og politikk trekkes frem:

Budskapet er systemfeil. Produksjonstankegangen har tatt overhånd og kontinuiteten mangler.

Om konsekvensene av at profitt styrer prioriteringer. Om dedikerte pleiere som jobber under hardt press. Om menneskets plass i helsesystemet.

Stykket får fram hvordan helsevesenet er dehumanisert. Noe som er styrt av økonomiske krefter. Dog viser teateret hvor dyrt det kan bli når pasienter blir behandlet som biomasse.

Disse sitatene er representative for studentenes umiddelbare tanker om hva stykket handler om. Vi ser at svarene kommuniserer både følelser og faglige begreper. Vi kan si at hvert sitat bærer i seg stemmene til både tilskuerposisjonen og studentposisjonen. Engasjementet er tydelig, det brukes kraftige og emosjonelt ladede uttrykk som produksjonstankegangen, profitt styrer, dehumanisert og behandlet som biomasse. Dette kan vi tolke dit hen at Omvlee sin fortelling om seg selv har vakt frustrasjon, fortvilelse og kanskje sinne. Samtidig ser vi at disse følelsene kommer til uttrykk gjennom faglige begreper og perspektiver som står sentralt i det aktuelle emnet. Teaterstykket vekker et emosjonelt engasjement som fyller de faglige begrepene med innhold, betydning og faktiske konsekvenser. Samtidig bruker studentene de faglige begrepene for å verbalisere egen opplevelse, sette fortellingen inn i fortolkningsrammer som skaper mening og sammenheng. Her husker vi Bakhtins 
forståelse av mening som en aktiv prosess. Mening oppstår når to eller flere stemmer kommer i kontakt, når lytterens stemme responderer på den som taler, slik at den som lytter, selv blir taler. Altså et møte mellom ulike konseptuelle systemer, og der stemmene blandes (Bakhtin, 1994). Slik sett illustrerer sitatene studentenes medforfatterskap der både Omvlee, pensumlitteraturen og studentenes egen stemme kommer til uttrykk (Rommetveit, 1999). Vi ser den samme flerstemmigheten når vi går til spørsmålet om egen opplevelse av det viktigste i stykket.

\section{Hva opplevde du som det viktigste i stykket?}

Dette spørsmålet inviterer til studentenes helt subjektive stillingtaking, men også her ser vi at svarene begrunnes faglig, samt at opplevelsen beskrives gjennom faglige begreper. Studentene trekker frem pasientsikkerhet og manglende kommunikasjon som viktige tema teaterstykket løfter fram. Men særlig interessant er studentenes sterke vektlegging av pasientperspektivet. Med støtte i Bakhtins perspektiv på dialogen er denne vektleggingen forståelig. Omvlee blottlegger seg selv, stiller spørsmål og målbærer et spekter av ulike følelser. Tilskuerne blir delaktige og forholder seg dialogisk ansvarlig til Omvlee «som $d u$, som samtalepartner, mitt andre jeg (...)» (Børtnes, 2001, s. 103). Dermed tas perspektivet til Omvlee som pasient, noe studentene uttrykker som:

At hun klarer å skildre sin optimisme og tillit til systemet samtidig som hun får frem usikkerheten og frykten hun opplever.

Muligens det viktigste hvor lite det syke mennesket har å si om sin egen sykdom, behandling og sitt liv.

Tankene/ordene hun formidler om det å være pasient. Som behandler er det vanskelig å sette seg inn i hvordan pasientene har det.

At behandlingsperspektivet ofte ser pasientene som objekter framfor subjekter. Ting skal være så effektive her og nå, uten at vi reflekterer over fremtidige utfordringer.

På nytt ser vi hvordan studentene knytter sin umiddelbare opplevelse av Omvlee sin fortelling til det faglige. Dette gjøres med utgangspunkt i den dialogiske relasjonen der Omvlee er samtalepartneren, tilskuerens $d u$. Men 
som vi husker, er Omvlee i henvendelse, en talende bevissthet som adresserer sine ytringer (Wertsch, 1993). Dermed er hver tilskuer Omvlee sin samtalepartner, et $d u$ som hun snakker med. I dette dialogiske møtet tar studentene stilling til Omvlee sine ytringer, egne disposisjoner mobiliseres og løftes frem. Slik kan studentene, med egne begreper, fullføre Omvlee sin framstilling av seg selv. Dette er å være medforfatter, et medforfatterskap som sitatene er eksempler på. Studentene gis muligheten til å danne seg et bilde av Omvlee som hun ikke er i stand til å danne ut fra seg selv (Bakhtin, 1994). Neste skritt blir å utfordre studentene på hvorfor dette opplevdes som viktigst, med andre ord en tydeligere utfordring på begrunnelse, og dermed refleksiv avstand til den umiddelbare opplevelsen.

\section{Hvorfor er dette det viktigste?}

Spørreadverbet hvorfor krever begrunnelse, og begrunnelse krever normalt sett en vurdering. Vanligvis vil den kommunikative invitasjonen, og utfordringen som ligger i et hvorfor, følges opp med subjunksjonen fordi, der det vises til de grunnene vurderingen er forankret i. Grunner er altså det som rettferdiggjør og argumenterer for våre synspunkter (Opdal, 2008). Vi kan se noen eksempler på dette i studentenes responser:

Fordi det fører med seg så enorme konsekvenser for enkeltindividet og samfunnet. Det handler om tillit og grunnleggende eksistensielle forhold: Hvem er jeg i det store bildet, hvem har ansvar for liv og død.

Fordi det la grunnlag for at pasientens situasjon ble bagatellisert. Stykket illustrerer flere elementer som peker på at kortsiktig økonomisk sparing er viktigere enn helse, sikkerhet og langsiktig perspektiv.

Vi har ofte hørt budskapet om at vi behandler en pasient, et menneske med følelser og ikke en ting. Likevel skjønner man dette bedre når man får føle på det selv - gjennom dette teaterstykket. Vi fikk oppleve konsekvensene av samhandlingsreformen 2012.

Igjen trer studentenes medforfatterskap tydelig frem. Vi hører deres stemmer som emosjonelt engasjerte, vi hører de faglige stemmene tilegnet gjennom utdanning og praksis, og vi hører også teaterstykkets multimodalitet bryte 
frem. Studentene etablerer med andre ord sine begrunnelser i møtet mellom flere stemmer. Dette kommer særlig godt fram i det siste sitatet. Her ser vi hvordan studenten viser til faglige/etiske prinsipper for hvordan pasienter skal behandles, men der stykket lar oss føle at et faglig/etisk ideal ikke alltid realiseres i en praktisk utført realitet. Refleksjonen sluttføres så i en tydelig kritikk av samhandlingsreformen fra 2012. Dette sitatet reiser en interessant problemstilling av pedagogisk art. Her har studenten åpenbart latt seg gripe emosjonelt av teaterstykkets univers, levd seg inn i handling og skjebner. Spørsmålet er hvordan granskning og vurdering av grunner er mulig når man er emosjonelt engasjert, når følelser bobler fram i samklang med teaterstykkets fortelling? Teologen Cornelius Plantinga (1997) viser hvordan vi som tilskuere til en viss grad er posisjonert ved at vi tillater oss selv å oppleve samsvarende emosjoner som kommer til uttrykk gjennom fortellingen. Sentralt er at posisjoneringen skjer i kombinasjon mellom ledetråder og invitasjoner i teaterstykket, og den kunnskaps- og erfaringshorisonten som ligger til grunn for tilskuerens individuelle orientering mot teaterstykkets fortelling. I likhet med blant andre filosofen Richard Wollheim (1999) og psykologen Richard Lazarus (1991) har Plantinga en kognitiv tilnærming til den emosjonelle opplevelsen ved at «what particular emotion I experience depends on my cognitions about my situation» (Plantinga, 1997, s. 378). Wollheim på sin side viser hvordan emosjoner, i kraft av å være mentale disposisjoner, utstyrer oss med en orientering eller holdning til de situasjonene vi befinner oss i. Det er med andre ord emosjonelle redskaper, ikke bare slik at vi kan fortolke, forstå og bevege oss i verden, men også som forutsetning for bearbeiding og endring av vårt eksisterende begrepsmessige rammeverk. Lazarus er enda mer spesifikk på hvordan emosjoner framstår idet en motivert interesse vurderes, noe som kommer tydelig fram i eksempelvis studentenes vurdering av samhandlingsreformens konsekvenser, eller hvordan økonomiske hensyn trumfer pasientsikkerhet. Poenget til Lazarus er at emosjoner gjør det mulig å søke kunnskap og forstålse som bekrefter, bevarer og beskytter den kunnskapen og de erfaringene som utgjør vår livsanskuelse, samtidig som de ber oss granske og vurdere våre holdninger, vår tro og våre forpliktelser. Disse endringene er «expansion of one's possibilities and areas of engagement, it is sometimes referred to as personal growth» (Lazarus, 1991, s. 138). Hos tilskueren oppstår det emosjonelle engasjementet umiddelbart, tett koblet til både hva som fortelles, og hvordan det fortelles. Tilskueren er i øyeblikkets opplevelse absorbert i sin egen emosjonelle tilstand. Her kan vi godt se for 
oss barnet, trollbundet av eventyret, eller ungdommen, paralysert av dukken i Annabelle (2014). Sosiologen Norman Denzin (1984) beskriver denne tilstanden som ikke-reflekterende, en tilstand der bevisstheten reflekterer $i$ seg selv, men ikke makter å tre ut fra seg selv og bli et objekt for selvrefleksjon. Studentene kan føle frustrasjonen som Omvlee formidler, de er $i$ den emosjonelle opplevelsen, en emosjonell opplevelse mobilisert av en aktiv og pågående vurdering. Idet teaterstykket er ferdig og studentene griper pennen og skriftlig verbaliserer sin opplevelse, ja, da beveger studentene seg gradvis over i en mer reflekterende posisjon der de klarer å se seg selv som emosjonelle deltakere i teateropplevelsen. Det skapes en distanse, en glidende overgang fra en ikke-reflekterende, emosjonell bevissthet til en reflekterende, emosjonell bevissthet, der «the person situates himself biographically in the emotional experience and reflects the emotion onto himself» (Denzin, 1984, s. 103). Det å reflektere over sin egen emosjonelle deltakelse er selvsagt ikke mulig uten først å ha vært i en emosjonell tilstand. Dermed gir teaterstykket oss en type refleksjoner som ikke ville vært der uten akkurat denne emosjonelle opplevelsen. Studentene uttrykker 1. persons opplevelser som er intensjonelt rettet (Goldie, 2000), og samtidig en intersubjektiv prosess der de har entret et annet menneskes tanker, følelser og slik leser deres bevissthet. Gjennom skriftlige responser distanseres det umiddelbare, og studentene synliggjør for seg selv sine egne emosjonelt forankrede vurderinger: Dette er slik jeg reagerer, dette er slik jeg tenker, dette er slik jeg foler. Dermed blir egen kunnskap, egne holdninger og verdier, ja, forståelsen og bruken av egen kunnskap avdekket. Slik kan studenten gå i dialog med egne vurderinger. De kan bekreftes, forsterkes, modereres, revurderes eller forkastes. Med andre, og litt spissformulerte ord, en distansert refleksjon over egne umiddelbare refleksjoner. Neste skritt i et pedagogisk opplegg vil være å bringe studentenes stemmer sammen i gruppe- eller plenumsarbeid. Her vil studentenes ulike vurderinger, tanker og refleksjoner i møtet med teaterstykket målbæres offentlig. Forskjellige stemmer møtes, og studentene besøker hverandres teateropplevelse og emosjonelt etablerte vurderinger og refleksjoner. Det legges til rette for meningsbrytning og aksept for perspektivpluralitet, ny forståelse vokser fram innenfor samtalen og et tekstlig fellesskap (Bruner, 1997, s. 81). Sammen gis altså studentene muligheten til å utveksle erfaringer og tenke over egen tenkning. Vi ser Rommetveits intersubjektive forståelse av læring i dette. Ulike stemmer kontrasterer, utfyller og beriker hverandre, noe som genererer læring og skaper ny kunnskap (Rommetveit, 1999). 


\section{En oppsummering av læringspotensialet}

Hvis vi går tilbake til Bakhtin sin dialogiske verdensanskuelse, så ser vi at ideer og tanker tar form, lever og utvikler seg, fornyer sitt verbale uttrykk i levende og genuine dialogiske relasjoner. Ja, våre tanker skapes, formes og endres i møter med andre stemmer. Disse andre stemmene kan vi møte i nær sagt alle mulige relasjoner og former der mennesker ytrer seg, alt fra steinalderens hulemalerier til vennesamtalen på Starbucks, fra inkafolkets arkitektur til den digitale verden i Fortnite, fra Hegels filosofiske verker til Stranger Things på Netflix. Teateret er også en plass der ulike stemmer møtes, og der vi kan dele og forhandle våre perspektiver. Særlig i forumteateret ser vi muligheten til å implementere teateret direkte i pedagogisk praksis som forelesninger og studiegrupper. Det å se et teaterstykke, se en film eller høre et musikkstykke representerer et brudd, et alternativ til den normale, planmessige og metodiske undervisningen. Pedagogen Erling Lars Dale beskriver dette som undervisningens diskontinuerlige mulighet, de øyeblikkene og hendelsene som bringer med seg noe nytt, noe umiddelbart og overraskende som bryter opp undervisningens daglige og kontinuerlige struktur. I kombinasjon med den didaktiske og planlagte undervisningen vil slike diskontinuerlige øyeblikk, som det å se et teaterstykke, kunne «omstrukturere den daglige virkelighet i nye rekkefølger ved å understreke det vesentlige. Sansingen intensiveres. Kunstverket overdriver når det fremholder det karakteristiske på en måte at en erkjenner at slik er det» (Dale, 1990, s. 94). Med en kognitiv forståelse av emosjoner, der mening og vurdering er involvert, vil studentenes emosjonelle engasjement være et resultat av en umiddelbar og refleksiv holdning til teaterets innhold og presentasjon. Kunnskap, holdninger og verdier utfordres og testes opp mot teaterstykkets virkelighet, noe som også betyr en verbalisering av det som ligger til grunn for egne vurderinger. Dermed erfarer studentene sin egen forståelseshorisont, og at denne kan evalueres og revideres idet teaterstykkets fortelling søker å få «lest» sine egne ord innenfor studentenes konseptuelle system. Det gjøres erfaringer som er nye, som utfyller hverandre eller opphever hverandre. Studentene flytter sine blikk, perspektivene endres og begrepene fylles med nytt innhold. Dette er kunnskapsbygging. 


\section{Referanser}

Bakhtin, M. (1981). Discourse in the Novel. I M. Holquist (red.), The Dialogic Imagination, s. 259-422. Austin: University of Texas Press.

Bakhtin, M. (1986). Speech Genres and Other Late Essays. Austin: University of Texas Press.

Bakhtin, M. (1994). The Dialogic Imagination. I P. Morris (red.), The Bakhtin Reader:Selected Writings of Bakhtin, Medvedev, Voloshinov, s. 74-80. London: Edward Arnold.

Bakhtin, M. (2003). Latter og dialog: Utvalgte skrifter. Oslo: J. W. Cappelens forlag.

Bakhtin, M. (2005). Spørsmålet om talegenrane. Bergen: Ariadne forlag.

Barthes, R. (1977). Introduction to the Structural Analysis of Narratives. I R.

Barthes Image, Music, Text, s. 79-124. London: Fontana.

Boal, A. (1985). Theatre of the Oppressed. London: Routledge.

Braaten, L.T., Kulset, S. \& Solum, O. (2000). Introduksjon til film: Historie, teori og analyse. Oslo: Gyldendal Akademisk forlag.

Bruner, J. (1997). Utdanningskultur og laring. Oslo: Ad Notam Forlag.

Børtnes, J. (2001). Bakhtin, dialogen og den andre. I: O. Dysthe (red.), Dialog, samspel og Laring, s. 91-105. Oslo: Abstrakt Forlag.

Chatman, S. (1978). Story and Discourse: Narrative Structure in Fiction and Film. Ithaca: Cornell University Press.

Clark, K. \& Holquist, M. (1984). Mikhail Bakhtin. Cambridge, Mass.: Harvard University Press.

Dale, E. L. (1990). Kunnskapens tre og kunstens skjønnhet: Om den estetiske oppdragelse $i$ det moderne samfunn. Oslo: Ad Notam Gyldendal.

Dalgard, O. (1974). Teatret frå Aiskylos til Ibsen. Oslo: Samlaget.

Denzin, N. K. (1984). On Understanding Emotions. San Francisco: Jossey-Bass.

Dostojevskij, F. (2001). Forbrytelse og straff. Oslo: Den norske bokklubben.

Dysthe, O. (1993). Det flerstemmige klasserommet: Skriving og samtale for å lere. Oslo: Gyldendal forlag.

Dysthe, O. (1996). «Læring gjennom dialog» - kva inneber det i høgare utdanning?

I O. Dysthe (red.), Ulike perspektiv på laring og laringsforskning, s. 88-104. Oslo: Cappelen Akademisk.

Dysthe, O. (2001). Sosiokulturelle teoriperspektiv på kunnskap og læring. I O.

Dysthe (red.), Dialog, samspel og laring, s. 33-72. Oslo: Abstrakt Forlag.

Engelstad, A. (2004). Poetikk og politikk. Augusto Boal og De undertryktes teater. Abo:

Åbo Akademis förlag. 
Gatland, J. O. (1998). Teaterteori: klassiske og moderne tekster. Oslo: Pax Forlag. Goldie, P. (2000). The Emotions: A Philosophical Exploration. New York: Oxford University Press.

Jacobsen, T. \& Baerheim, A. (2005). Elements from Theatre Art as Learning Tools in Medical Education. Research in Drama Education, 10(1), s. 5-14.

DOI: https://doi.org/10.1080/13569780500053072

Lazarus, R. S. (1991). Emotion and Adaption. New York: Oxford University Press.

Lothe, J. (1994). Fiksjon og film: Narrativ teori og analyse. Oslo: Universitetsforlaget.

Omvlee, C. (2017). Langligger. Trondheim: Teater Fusentast.

Opdal, P. (2008). Pedagogisk - filosofiske analyser. Bergen: Fagbokforlaget.

Pammenter, P. (2013). Theatre as Education and a Resource of Hope: Reflections on the Devising Participatory Theatre. I A. Jackson \& C. Vine (red.), Through the Changing Face of Theatre in Education, s. 83-101. London: Taylor and Francis.

Plantinga, C. (1997). Notes on Spectator Emotion and Ideological Film Criticism. I: R. Allen \& M. Smith (red.), Film Theory and Philosophy, s. 372-393. New York: Oxford University Press.

DOI: https://doi.org/10.1093/acprof:oso/9780198159216.003.0017

Rommetveit, R. (1996). Læring gjennom dialog: Ei sosiokulturell og sosiokognitiv tilnærming til kunnskap og læring. I O. Dysthe (red.), Ulike perspektiv på laring og Laringsforskning, s. 88-104. Oslo: Cappelen Akademisk.

Rommetveit, R. (1999). Om dialogisme og vitskapleg disiplinert diskurs - og samtaleanalyse. Norsk Lingvistisk Tidsskrift (1) s. 15-37.

Smith, M. (1995). Engaging Characters: Fiction, Emotion, and the Cinema. New York: Oxford University Press.

Wertsch, J. V. (1991). Voices of the Mind: A Sosiocultural Approach to Mediated Action. Cambridge, Mass.: Harvard University Press.

Wertsch, J. V. (1998). Mind as Action. New York: Oxford University Press. DOI: https://doi.org/10.1093/acprof:oso/9780195117530.001.0001

Wollheim, R. (1999). On the Emotions. New Haven: Yale University Press. 